\title{
ATUALIZAÇÃO NO DIAGNÓSTICO DO CÂNCER DE BEXIGA
}

\section{Sidney Glina, Wanderley Marques Bernardo}

\section{TEMA ABORDADO}

Especialidade de abrangência: U rologia, Patologia e 0 ncologia.

Diretriz a ser consultada: Câncer de bexiga - Diagnóstico

\section{Cenários e questões CLínicas}

1. 0 sintoma mais freqüente do câncer de bexiga é a hematúria, caracterizada por ser:

a. Associada à disúria

b. Macroscópica ou microscópica

c. Constante

d. Dolorosa

e. Todas as alternativas são corretas

2. Q uando a cistoscopia é negativa para câncer de bexiga:

a. Está afastado o diagnóstico de câncer de bexiga

b. Deve ser repetido o exame

c. É possível que haja o diagnóstico de carcinoma "in situ" ( $C$ is)

d. Utilizar luz especial e fotossensibilizadores, disponíveis no Brasil

e. Isso demonstra que a cistoscopia não é a conduta padrão

3. São desvantagens da citologia urinária:

a. Especificidade do método

b. Ser invasiva

c. A dificuldade para a coleta

d. Sensibilidade do método

e. Critérios muito objetivos

4. A investigação de tumor no trato superior urinário associado ao câncer de bexiga de alto grau deve ser preferencialmente realizada por meio da:

a. Ressonância magnética

b. Citologia urinária

c. Ultra-sonografia

d. Ureteroscopia

e. Urografia excretora

5. 0 diagnóstico definitivo do câncer de bexiga é realizado pela ressecção transuretral. Em relação a este método diagnóstico, é verdadeiro:

a. As biópsias de mucosa normal estão sempre indicadas

b. Na suspeita de Cis plano realizar biópsias de uretra prostática

c. O s componentes: superficial e profundo, do tumor, devem ser ressecados juntos

d. A segunda ressecção transuretral não está indicada

e. A palpação da lesão deve ser feita depois de sua ressecção

\section{Respostas do Cenário clínico: Atualização, na assistência pré-natal (Parte III), baseada em} eVidênCia e Centrada no paciente. [Publicado na RAMB 2008; 54(2)]

1. Mulheres com recém-nascidos que apresentam defeitos do tubo neural devem manter a suplementação pré-concepcional até a 12 a semana gestacional (Alternativa $\mathbf{C}$ ).

2. A suplementação de ferro durante a gestação reduz o risco de a paciente apresentar, ao final da gravidez, hemoglobina com nível inferior a 10,0 g/dL (Alternativa A).

3. Em relação à suplementação de vitaminas durante a gestação, é falso afirmar que a suplementação de vitamina $D$ reduz 0 baixo-peso ao nascer (Alternativa B).

4. A dopplervelocimetria da artéria umbelical reduz o índice de internação hospitalar em gestação de alto risco (Alternativa C).

5. 0 uso da ultra-sonografia no perío do gestacional na segunda metade não reduz a prematuridade (Alternativa D). 